\title{
O teatro da cura cruel
}

Ana Teixeira ${ }^{1}$

1 "Eu represento minha vida" - O verbo jouer em francês tem um sentido muito amplo. Significa "atuar", "representar",

"interpretar" mas também "jogar", "brincar", "arriscar". No teatro, o ator é aquele que "joue", a tradução freqüentemente encontrada em português é

"interpreta" mas, no caso de Artaud, o correto seria uma palavra que reunisse o sentido de "atuar" e "arriscar".

2 Jacques Rivière era o editor da Nouvelle Revue Française em 1924. Artaud envia seus primeiros poemas (Tric Trac du Ciel) a Rivière, mas este recusa a publicação, justificando que ainda são imaturos. Artaud inicia uma correspondência com o editor, não para justificar a qualidade de seus poemas mas para reivindicar o direito à sua existência, para afirmar a necessidade de escrevêlos e a autenticidade das questões ali colocadas. "Me falta a concordância entre as palavras e o minuto de meus estados". Rivière propõe a Artaud a publicação desta correspondência, que aparecerá em 1927.

${ }^{3}$ Le Théâtre et son Double Coleção Folio/Essais - Ed. Gallimard, 1964. Coletânea de textos, manifestos e conferências concluídas em 1935.
Antonin Artaud nasceu na França em 1896. Foi poeta, pintor, escritor, ator e dramaturgo. Seu percurso marcou de modo decisivo áreas tão abrangentes como a literatura, o teatro, a pintura, a filosofia, a medicina e a antropologia.

Je joue ma vie ${ }^{1}$, declarava Antonin Artaud, e não era uma metáfora. Sua vida é tão ligada à sua obra que poderíamos quase dizer que ele escreveu com a própria vida.

$O$ sofrimento físico e mental de que padece e que exprime em sua correspondência com Jacques Rivière ${ }^{2}$ em 1923, o leva a fazer uso do ópio sob prescrição médica desde os quinze anos de idade. A droga o alivia, mas o obriga a terríveis tratamentos de desintoxicação. Sua vida foi uma eterna procura da cura de sua "pavorosa doença do espírito". Poesia, escritura, pintura, desenho, viagens e esoterismo são formas diversas de uma mesma busca. Nesta busca, o teatro e, em particular, a profissão de ator, ocupa um espaço privilegiado. A cena é o lugar eleito para a cura da dor e da impotência intelectual e criativa decorrente dela; o lugar para recuperar uma nova identidade, não-dividida, mediante uma "síntese superior do físico e do espírito". Ser ator é a primeira vocação de Artaud; o teatro se apresenta do início ao fim como espaço terapêutico, a cena é " $a$ possibilidade de nascer outro", de regenerar o ser.

Esta consciência o leva a coincidir sempre sua busca pessoal com a busca de um teatro orgânico, eficaz, necessário, que possibilite ao homem se reencontrar, ou mesmo renascer. Este é o sentido da relação fortíssima, já apontado nos anos trinta no Teatro e seu Duplo ${ }^{3}$, entre teatro e vida.

${ }^{1}$ Encenadora e professora de interpretação teatral, diretora do espetáculo Cartas de Rodez (1998), com texto de Antonin Artaud, que recebeu o prêmio Shell de melhor ator e melhor direção e o prêmio Mambembe de melhor espetáculo. 
Um teatro eficaz é aquele capaz de refazer a vida, o que não seria possível sem refazer profundamente a cultura no Ocidente. Toda a obra de Artaud foi guiada pelo desejo incessante de reencontrar um ponto de utilização mágica das coisas, recusando uma consciência estética fundada em simulacros, aparências face à realidade empírica das coisas. Ele coloca a questão da linguagem e da manipulação de signos em termos de forças mágicas e da relação mantida, através deles, com o cosmos e com o divino. Para Artaud, o Ocidente europeu é doente porque separado, pois perdeu sua ligação com o divino, com a consciência cósmica.

\section{As Cartas de Rodez}

Em 1937, Artaud recebe um bastão mágico proveniente de um feiticeiro da Savóia, que ele acreditava ser o bastão de São Patrick, patrono dos Irlandeses. É para a Irlanda que ele parte, afim de devolvê-lo ao seu lugar de origem e de encontrar traços da cultura celta. Vivendo em condições precárias, em um país onde ele mal domina o idioma, Artaud vive pregando nas ruas com seu bastão. Acusado de ser um agitador e de vagabundagem, é preso e enviado, num barco, pela polícia de volta para a França. Um incidente ocorrido durante a viagem fez com que ele fosse, a partir de 1937, internado como louco em estabelecimentos psiquiátricos.

Ao sofrimento do afastamento, às brutalidades de uma vida comunitária imposta, aos odores da promiscuidade, e às privações da vida em um manicômio, adicionou-se com a Ocupação alemã em maio de 1940, as carências alimentares. Assim, em Ville-Évrard ${ }^{4}$, além de sua dignidade e de sua liberdade, Artaud começou a ser privado de seu corpo. Subnutrido, ele se torna um esqueleto, uma sombra dolorosa que tenta manter a vida. Suas cartas, as poucas que se conhece, são longas reivindicações de comida.

"E se ainda estou vivo, Euphrasie, é por ter uma constituição anormalmente resistente e também por um perpétuo milagre de Deus mas, na realidade, sou só um cadáver vivo e que se vê sobreviver e vivo aqui com angústias de morte." 5

Artaud ficará esquecido até 1943, quando seus amigos se moverão para salvá-lo. A pedido do poeta Robert Desnos, ele é transferido a Rodez pelo Dr. Ferdière, médico-responsável deste manicômio. Ligado ao movimento surrealista, o médico conhecia Artaud e era um admirador de seu trabalho. Desde sua chegada em Rodez, Artaud inicia uma intensa correspondência com seus amigos, mas também com o médico. Por essas cartas percebemos uma relação ambígua entre os dois: livrando Artaud dos manicômios onde esteve internado em condições extremamente precárias e fazendo com que fosse transferido a Rodez, o médico salva sua vida $e$, como reconhece o gênio do poeta, o incentiva a retomar sua atividade literária. Ao mesmo tempo, julgando a poesia de seu paciente muito delirante, ele o submetia a violentos tratamentos de eletrochoque, prejudicando seu corpo e sua memória. Apesar da relação de amizade que se estabeleceu entre os dois, o Dr. Ferdière mantinha Artaud privado de sua liberdade e de sua dignidade, obrigando um homem que possuía todos os meios de sua maturidade para trabalhar e se manter, a viver sob a tutela de médicos em um regime de promiscuidade, com pacientes que nada tinham em comum com ele. As cartas são para Artaud um recurso para não perder sua lucidez e testemunhos de um homem em terrível estado de sofrimento $e$ de solidão.

\author{
${ }^{4}$ Manicômio \\ francês onde \\ Artaud \\ permaneceu três \\ anos, que se \\ encontrava em \\ zona ocupada \\ pelos alemães.

\footnotetext{
${ }^{5}$ Carta do 23 de março 1942 à Mme. Artaud. Tradução Ana
} \\ Teixeira.
}


"Vejo na sua proposta de me trazer aqui e de cuidar diretamente de mim o desejo de fazer justiça a um homem internado sem razão. Mas

tem uma coisa que é inadmissível na minha situação aqui. Já faz quinze dias que pedi ao Dr. Latrimolière que me deixasse tomar banho todos os dias para me manter limpo. Pedi-lhe também que evitasse me incluir no banho coletivo pois a aproximação de todos os corpos nus e o odor dos gazes mefiticos que alguns doentes exalam ofendem minha castidade, e o que me responderam é que não havia água quente. Pedi ainda que me fizessem a barba pelo menos a cada dois dias e o barbeiro me disse que não tinha tempo. E faz dois meses que o senhor prometeu me mandar uma escova de dentes e até agora não me mandou. O senhor bem pode notar que

estou sendo maltratado, e poderá notar que também me trata muito mal, e no fim é a mim que o senhor censura dizendo que não me cuido bem. Suas reprovações me feriram o coração, são uma afronta que preferia não ter ouvido da boca de um amigo. Sempre me preocupei com a higiene de meu corpo e apesar de meu enorme cansaço vou procurar todos os instrumentos de que preciso além de uma escova de dentes. Mas será que o senhor não notou que quase não tenho mais dentes, e que dos trinta e três que tinha só sobraram oito. Parece que o senhor já se esqueceu de como os perdi. É cruel, Dr. Ferdière, censurar um homem ferido e acidentado por maus tratos de não escovar os dentes ao saber que este mesmo homem perdeu os dentes por desgraça". ${ }^{6}$

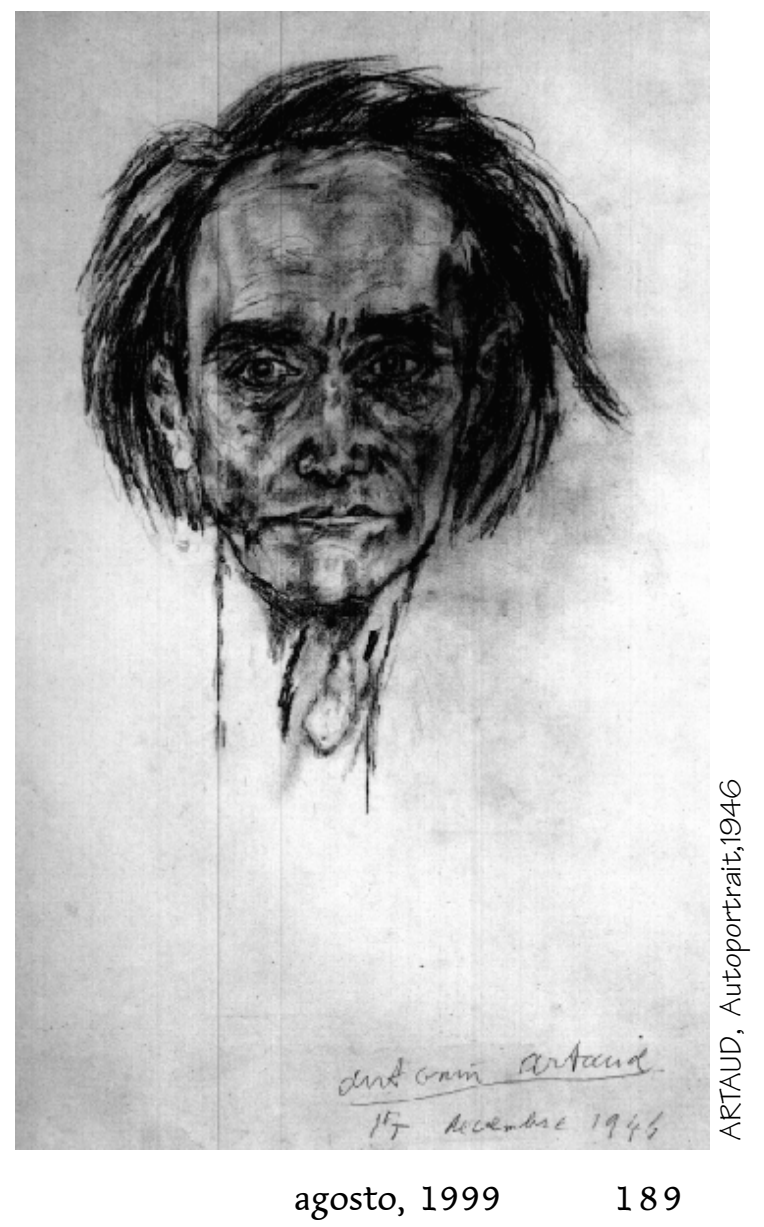

${ }^{6}$ Montagem de cartas em 12 de fevereiro $e$ 18 de maio de 1943 . Extraído do texto do espetáculo Cartas de Rodez. Tradução Lilian Escorel. 
Artaud chega em Rodez em janeiro de 1943. Pouco a pouco ele se refaz, recupera seu peso, seu corpo e também sua mente. Em junho estimam que já está restabelecido o bastante para resistir à brutalidade da sismoterapia, e ele é submetido a uma série de eletrochoques.

O eletrochoque, tal como era praticado nessa época, é uma extraordinária barbárie. De uma crise de epilepsia provocada, o doente acorda abobalhado após um coma que dura longos minutos. O eletrochoque abala o pensamento, tornando-o confuso, faz o paciente mergulhar "neste estertor por onde se deixa a vida" e de onde ele volta com a lembrança atroz de ter sido esvaziado de seu eu.

Já na segunda sessão, o corpo de Antonin Artaud não suporta a violência das convulsões e ele sai com fortes dores na coluna vertebral. Assim mesmo, os médicos persistem. Depois do terceiro eletrochoque, elas se tornam insuportáveis, a nona vértebra dorsal é fraturada e o médico deve abandonar este tratamento que causou tantas desordens: será necessário dois meses de leito e de cuidados apropriados antes do corpo poder ficar de pé. No final de outubro do mesmo ano, seu sistema ósseo é considerado bastante sólido para recomeçar o tratamento. Ele é submetido ainda 12 vezes ao eletrochoque e no ano seguinte três outras séries de 12 são impostas. A cada vez ele se revolta, protesta, suplica e fala, com uma lucidez extraordinária, das razões que ele tem para condenar esta prática :

"O eletrochoque me desespera, tira minha memória entorpece meu pensamento e meu coração, transformame num ausente que se percebe ausente e se vê durante semanas perdido em busca de seu ser como um morto ao lado de um vivo. Na última série eu fiquei durante todo o mês de agosto e setembro absolutamente impossibilitado de trabalhar, de pensar e de me sentir ser. Peço que me poupe de uma nova dor, isto me fará repousar, Dr. Ferdière, e preciso muito de um repouso." ${ }^{7}$

No entanto a medicina, esta medicina que "mente a cada vez que ela apresenta um doente curado pelas introspecções elétricas de seus métodos, continua a pretender curá-lo atravessando seu corpo com descargas elétricas, jogando seu ser no abismo em 51 comas durante os três anos passados em Rodez. Mas graças a que recursos este homem cujo corpo e mente sofreu tal violência conseguiu não se aniquilar?

\section{O Teatro da Cura Cruel}

Em Rodez, quando ele sente a possibilidade de voltar para a vida exterior, a idéia do teatro reaparece. A produção literária de Artaud neste período é marcada pela forma epistolar, reveladora de seu desejo de "dramatizar a escrita", de escrever sempre para alguém, para um leitor-espectador.

Além de recomeçar a escrever e desenhar, ele se dedica a uma intensa $e$ quotidiana prática vocal, exercitando sua respiração e seu corpo, praticando cantos e giros conjuratórios que eram também um meio para lutar contra

\author{
${ }^{7}$ Montagem de cartas \\ escritas ao Dr. \\ Latrimolière ( 6 janeiro \\ de 1945) e ao Dr. \\ Ferdière ( 24 de \\ outubro de 1943). \\ Extraído do texto do \\ espetáculo Cartas de \\ Rodez. Tradução Lilian \\ Escorel.
}


${ }^{8}$ O teatro de Serafim é um texto escrito para a revista Mesures que deveria entrar na composição do Teatro de seu Duplo. Ele só foi publicado em 1948 na coleção Air du Temps. os feitiços maléficos que o cercavam.

Este trabalho, ele o repetiu quotidianamente depois de seu retorno a Paris. A energia que ele produzia, as forças que emanavam de seu corpo enfraquecido, as incríveis variações de altura que obtinha de sua voz, a intensidade e a duração dos gritos aconteciam como um fenômeno de operação mágica. Este era o Teatro da Cura Cruel, um teatro que não precisa de sala, onde o lugar é o corpo do homem proferindo sua vida. Esta prática foi decisiva para a volta de Antonin Artaud à vida $e$ à poesia.

Mas estes cantos e giros eram censurados pelo médico-chefe do hospital psiquiátrico. Era desconhecer grosseiramente a teoria do grito e do sopro, do corpo do homem como lugar primordial do ato teatral que ele já tinha formulado nos anos trinta com o atletismo afetivo e o Théâtre de Séraphin ${ }^{8}$.

Ele faz questão de deixar claro que esta prática é uma lúcida determinação, ligada ao ato de criação, e que não tem nada a ver com uma demonstração de inconsciência. Ele sempre protestava quando seus cantos escandidos eram usados como provas de sua perturbação mental. Eram cantos que acompanham um desenho ou um poema e que ele transpunha como suporte de um signo escrito ou desenhado.

"O senhor esquece que eu também fui encenador e que todas as peças que fiz eram baseadas numa utilização particular da salmodia e da encantação. Isto é doença mental?"

Artaud resistiu em Rodez pela escrita e pelo trabalho que ele impunha a seu corpo e à sua voz, trabalho este que é uma outra forma de escritura.

O homem privado de sua liberdade mais elementar foi também privado de seu próprio corpo. Este mesmo corpo cujo funcionamento anárquico o fez sofrer "os estados de dor errante e de angústia". Mas o terrível estado de reclusão psiquiátrica constituiu para Artaud uma extraordinária experiência cognitiva. Quando voltou a Paris em 1946, depois de passados 9 anos em manicômios, ele se denomina Artaud, o Mômo, como Artaud, o Louco, o Bufão. Depois de ter sido tanto tempo considerado louco, agora ele sentia prazer em se fazer de louco para dizer certas verdades. Uma destas verdades essenciais diz respeito ao nosso corpo. O corpo atual, desconectado da origem, é o resultado de uma manipulação perpétua e perversa em conseqüência da qual "sua anatomia, que deixou de corresponder à sua natureza”, deve ser refeita. No final de sua vida e de seu percurso artístico, Artaud concebe o Teatro da Crueldade como um grandioso projeto éticopolítico de insurreição física: trata-se de transformar a cena para que o homem $e$ não somente o ator possa refazer sua anatomia, possa reconstruir um "corpo sem órgãos". Este refazer baseia-se na idéia da decomposição $e$ recomposição do corpo e visa essencialmente a desarticulação dos automatismos que condicionam e bloqueiam o indivíduo e o impedem de agir realmente, de modo consciente e voluntário, em cena ou na vida. Depois de Rodez, o Teatro da Crueldade é o teatro de um violento refazer do corpo. 


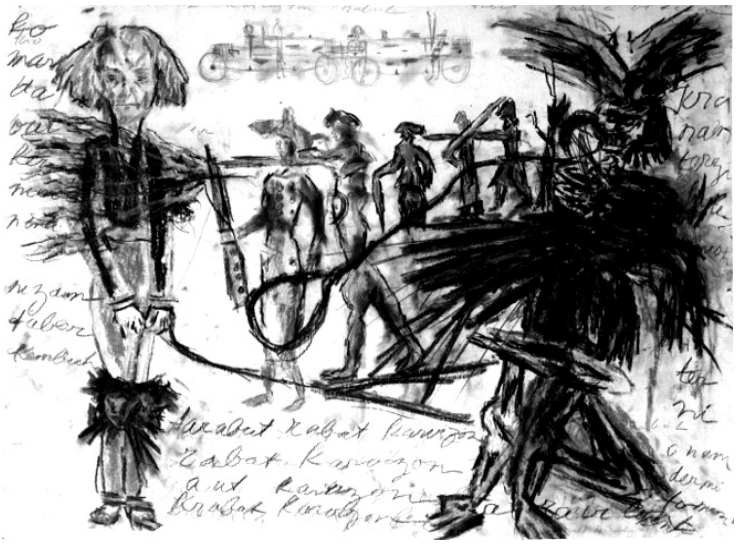

ARTAUD, La projection du veritable corps, 1948

Em 1938, o célebre psicanalista francês Jacques Lacan, depois de ter visitado Artaud no Hospício de Sainte-Anne, onde já estava internado há um ano, declarou : "Está fissurado, viverá até oitenta anos, não escreverá mais uma linha, está fissurado". As previsões do futuro guru da psicanálise foram completamente desmentidas: dos 26 volumes que compõem as obras completas, somente oito são escritos compostos antes de 1937, isto é, antes que iniciasse o calvário das internações. Artaud morreu em 1948, aos 52 anos. 